\title{
Correction: Cost-effectiveness of strategies preventing late-onset infection in preterm infants
}

Grosso A, Neves de Faria RI, Bojke L, et al. Cost-effectiveness of strategies preventing lateonset infection in preterm infants. Arch Dis Child 2020;105:452-7.

The authors have noticed an error in table 1 of their article. The values for 'Healthcare costs between 6 months and 2 years' in table 1 should be amended as follows:

- Value GA 23-27 weeks (95\% CI): $£ 5989.17$ (5983.44 to 5994.98)

- Value GA 28-32 weeks (95\% CI): $£ 3026.43$ (3024.21 to 3028.73).

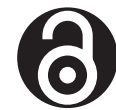

\section{OPEN ACCESS}

Open access This is an open access article distributed in accordance with the Creative Commons Attribution 4.0 Unported (CC BY 4.0) license, which permits others to copy, redistribute, remix, transform and build upon this work for any purpose, provided the original work is properly cited, a link to the licence is given, and indication of whether changes were made. See: https://creativecommons.org/licenses/by/4.0/.

(C) Author(s) (or their employer(s)) 2021. Re-use permitted under CC BY. Published by BMJ. Screen reader support enabled. Arch Dis Child 2021;106:e1. doi:10.1136/archdischild-2019-317640corr1

(D) Check for updates 